\title{
Vulnerable Consumers, their Health and Urgent Supply of Electrical Energy in Slovenian Legal Framework
}

\author{
LUKA MARTIN TOMAŽIČ, SUZANA BRAČIČ \& BORUT BRATINA
}

\begin{abstract}
The question of access to a cost-accessible source of electrical energy during the winter months is one of the pressing concerns of social security even in developed states. We will analyse the complex legal, health and economic issues that are connected with the notion of who a vulnerable consumer is as defined in the Slovenian Energy Code (EZ-1). We will do so by analysing the nature of electrical energy in the Slovenian legal framework and then by evaluating the legal solutions proposed for vulnerable consumers. Consequences for an individual's health, with a focus during the winter months, will be assessed and a comparative overview of legal solutions will be performed. Lastly, we will argue that the current solution may well be economically untenable and that a revision might be in order.
\end{abstract}

Keywords: - Energy Poverty - Vulnerable Consumers • Cold Exposure $\bullet$ Urgent Supply $\bullet$ Electricity $\bullet$ Slovenia $\bullet$

CORRESPONDENCE ADDRESS: Luka Martin Tomažič, PhD, Teaching and Research Assistan, New University, European Faculty of Law, Delpinova ulica 18B, 5000 Nova Gorica, Slovenia, e-mail: luka.tomazic@gmail.com. Suzana Bračič, MSc Candidate, Resident in Pathology, Medical University of Graz, Auenbruggerpl. 2, 8036 Graz, Austria, e-mail: suzana.bracic@kages.at. Borut Bratina, PhD, Full Professor, University of Maribor, Faculty of Economics and Business, Razlagova ulica 14, 2000 Maribor, Slovenia, e-mail: borut.bratina@um.si. 

Energy poverty is often defined as 'the situation in which individuals or households are not able to adequately heat their homes or meet other required energy services at affordable cost.'(Rademaekers et al., 2016: 5) According to a policy report from 2015, 'Energy poverty and vulnerable consumers in the energy sector across the European Union (EU): analysis of policies and measures', Slovenia is designated as a category $\mathrm{C}$ state, meaning that 'the definition of the concept of vulnerable customers is implicitly recognized by the energy law and/or social security system.'(Pye, 2015: 31) Although the above designation is based on the old Energy Act, the provisions regarding vulnerable consumers remain in their essence unchanged and therefore the classification has not lost its relevance. This article will argue that adequate and comprehensive socio-legal solutions addressing the needs of vulnerable consumers seem to be lacking in Slovenia. This is especially the case since the executive regulations are wrongfully limiting the scope of the main provision relating to energy poverty and to vulnerable consumers, because the law as it is written is not actually being applied in practice, especially when taking into account the relevant research in the field of medical science.

To show the above statement to be true, the nature of electrical energy in the Slovenian legal system will first be evaluated. Next, the main provision aimed at alleviating energy poverty and granting protection to vulnerable consumers, namely the provision relating to urgent supply, will be analysed. It will be shown that a question of medical science lies at the heart of the provision, specifically the question of what the indoor temperatures are, which are by themselves hazardous to human health. This is especially important during the winter months, when certain individuals cannot secure sufficient funds to ensure themselves an adequate source of heating. The problems related to executive regulation will be emphasized and practical application of the rules will be criticized. Lastly, a short comparative overview will be made, encompassing differing solutions that different states have applied to battle energy poverty and grant protection to vulnerable consumers. A proposal will be made, especially in light of potential economic consequences of the studied provisions. 
L. M. Tomažič, S. Bračič \& B. Bratina: Vulnerable Consumers, their Health and Urgent Supply of Electrical Energy in Slovenian Legal Framework

\section{The Nature of Electrical Energy in the Slovenian Legal System - a Commodity with Certain Ppublic Good Elements}

Electricity is often thought of as a public good, however it will be shown that such an assertion is oversimplified and mistaken, not least in the Slovenian legal framework. Such a mistaken viewpoint is often stated in the media ${ }^{1}$ and sometimes even in court practice. ${ }^{2}$ It is however more accurate to speak of electrical energy as a sui generis commodity; a market good or commodity with certain specific characteristics, which are typical of public goods, especially in terms of network access for vulnerable consumers.

A commodity is usually defined as a desired private good, the purpose of which is the fulfilment of needs of individuals (Bates, 1990: 382). It is traded on a free, liberalized market, and its price is set by supply and demand, namely by the operation of free market principles. On the other hand, public goods are those provided of which are in the interest of the broader public and have to be noncompetitive and non-exclusionary. In the broader sense, welfare goods, which have a social justice dimension or teleology are sometimes understood as public goods as well, however public goods strictu sensu have no normative implications but merely meet the conditions of basic availability and open access (Kalihoff, 2011: $21,22)$.

Non-competitiveness means that free market characteristics cannot be applied to such a good and that if one person enjoys the good this does not diminish the ability of other people to enjoy the same good; non-excludability is connected to the idea that individuals cannot be prevented from enjoying such a good (Kotchen, 2012). Access to electrical energy in the Republic of Slovenia is both competitive and excludable as a basic rule; it is namely provided to vulnerable consumers on a liberalised, competitive market in a non-excludable way only as an exception, as a sort of social corrective.

The element of competitiveness stems from the fact that the EU energy markets were liberalized with the so-called 'energy packages', or legislation bundles aimed specifically at making the energy markets of the European Union more competitive, therefore lowering the cost of electricity for consumers. Individual suppliers buy

\footnotetext{
1 STA: Na okrogli mizi o (ne)smiselnosti privatizacije energetike (2014), available at: https://krog.sta.si/2053846/na-okrogli-mizi-o-ne-smiselnosti-privatizacije-energetike (August 8, 2018).

${ }^{2}$ VSL sodba I Cpg 1121/2011 (2011), available at:

http://www.sodnapraksa.si/?q=id:2012032113048659\&database[SOVS]=SOVS\&database[ IESP]=IESP\&database[VDSS]=VDSS\&database[UPRS]=UPRS\&_submit=i\%C5\%A1\%C 4\%8Di\&page $=0 \&$ rowsPerPage $=20 \&$ moreLikeThis $=1 \&$ id $=$ doc_2012032113043324 (August 8, 2018).
} 
limited amounts of electricity from producers and supply them to individual consumers in accordance with agreed upon conditions. Thus if one person enjoys such a good, it is clear that it indeed does diminish the ability of other people to enjoy the same good, at least to a certain degree. The Slovenian electricity market was, after a reasonably long vacatio legis, liberalized for household consumers in 2007, due to an amendment to the Energy Code from 2004. ${ }^{3}$ The key date from which electricity became a full commodity for household consumers in Slovenia is therefore 1 July 2007. It also denotes the date when the nature of electrical energy changed in Slovenia, from a public good, to a commodity with certain public good characteristics.

The element of exclusionary nature is evidenced by Article 151 of the Energy Code (EZ-1), which determines the factual circumstances in which the operator disconnects an individual consumer from the electricity grid. The most important of those is point g) paragraph 1 of Article 151, which states that an individual consumer will be disconnected in such a case where a supply contract between a provider and consumer does not exist or has been terminated. Since the supply contracts are entered into in a liberalized market on a voluntary basis, it is clear that electrical energy is a good with exclusionary nature, according to the Slovenian legal system. Also, the historical development of the energy legislation leads us to the same conclusion. The old Energy Code (EZ) had a specific provision (Article 46 of EZ), which stated that '...providing the supply of energy and services under common conditions to everyone...' was the obligation of the operators of commercial public services. ${ }^{4}$ Such a provision is not present in the contemporary EZ-1, thus evidencing a clear shift in the economic and legal nature of electrical energy in the electro-energy system of the Republic of Slovenia.

The nature of electrical energy as a commodity in the Slovenian legal system is, notwithstanding the access to electrical energy, which has some elements of a public good, a commodity sui generis. This stems from the international obligations of the Republic of Slovenia, for example from the Convention on the Elimination of All Forms of Discrimination Against Women (CEDAW), which states in point $\mathrm{H}$ of the second paragraph of article 14, that a human right is also the right to 'adequate living conditions, particularly in relation to housing, sanitation, electricity and water supply, transport and communications. ${ }^{5}$ What is meant from the above wording is the right to have access to the electricity grid under affordable prices for each individual. Certain social correctives for those who cannot afford an alternative source of heating in the winter months and those with special needs, is also to be

\footnotetext{
${ }^{3}$ EZ-A (2004), available at: https://www.uradni-list.si/glasilo-uradni-listrs/vsebina?urlurid=20042307 (March 12, 2018).

${ }^{4}$ EZ (2007) with amendments, available at: http://www.pisrs.si/Pis.web/pregledPredpisa?id=ZAKO1550 (March 12, 2018).

${ }^{5}$ Convention on Elimination of All Forms of Discrimination Against Women (1979), available at: http://www.un.org/womenwatch/daw/cedaw/cedaw.htm (March 12, 2018).
} 

and Urgent Supply of Electrical Energy in Slovenian Legal Framework

expected. That access to electric energy is a component of the human right to the adequate standard of living, is a well-known viewpoint from the relevant human rights literature (Bradbrook et al, 2006).

Such special nature of electrical energy is mirrored on the legislative level as well, where the Code of Commercial Public Services (hereinafter ZGJS) ${ }^{6}$ states in Article 1 the commercial public services:

“...provide material public goods as products and services, the permanent and uninterrupted production of which provides the Republic of Slovenia or a municipality or other local community in public interest for the satisfaction of public needs, when and to the extent to which it is not possible to provide them in the market."

Since access to the electricity grid (but not to electricity itself) is provided in the corporate form of a commercial public service in accordance with ZGJS and EZ-1, it is clear that access to electricity is a public good and therefore electricity itself has certain elements of a public good in the Slovenian legal system (Tomažič \& Bratina, 2015: 22). Individuals namely cannot be excluded from the access to the electrical grid, and the enjoyment of access generally does not exclude other individuals from enjoyment of the same, especially taking into account the demand for the security of supply from Article 37 EZ-1.

\section{$3 \quad$ Article 51 of the Energy Code}

The main legislative tool aimed at alleviating energy poverty and ensuring the providing of the public good of access of electricity network even for those individuals whose social situation prevents them from ensuring an alternative affordable source of heating during the winter months is the provision related to vulnerable consumers and urgent supply in the EZ-1.

It is in line with the predominant approach taken at the level of European Union, where the notions of energy poverty and vulnerable consumers are the main conceptual tools used for addressing the needs of non-privileged individuals regarding electricity consumption. ${ }^{7}$ The normative approach of the European Union has on the other hand been remarkably vague, requiring Member States merely to put forth a definition of vulnerable consumers in their national legislations and to

6 Code of Commercial Public Services (1993) with amendments, available at: http://www.pisrs.si/Pis.web/pregledPredpisa?id=ZAKO272 (March 12, 2018).

${ }^{7}$ European Commission, Vulnerable Consumer Working Group Working Paper on Energy Poverty, available at:

https://ec.europa.eu/energy/sites/ener/files/documents/Working\%20Paper\%20on\%20Energ y\%20Poverty.pdf (August 10, 2018). 
protect them. ${ }^{8}$ There are neither unified definitions put forth at the European Union level, nor is there a consensus as to how to actually measure energy poverty in methodological terms.

Article 51 of the Slovenian EZ-1, titled 'vulnerable consumers and urgent supply' states as follows:

(1) A vulnerable consumer is a household consumer, who due to his financial situation, income and other social circumstances and living conditions is unable to ensure himself another source of energy for household use, which would cause him the same or lower costs for the most urgent household supply.

(2) Distribution operator may not disconnect a vulnerable consumer from electricity network or lower his withdrawal of energy under the quantity or power, which is according to circumstances (season, temperature conditions, place of habitation, health condition and other similar circumstances) absolutely necessary, that an endangerment of life and health of the consumer and persons living with him does not occur.

(3) Distribution operator must inform the consumer before the disconnection of the possibility of urgent supply, of the evidence, which the consumer needs to present to the operator, so that the operator may grant him urgent supply and of the deadlines in which this evidence must be presented. More detailed conditions and price of urgent supply, which covers the expenses of energy purchase, is prescribed by the operator in the system operating instructions from the Article 144 of this Code in accordance with the rules and criteria, prescribed by the Energy Agency.

(4) Expenses of urgent supply of vulnerable consumers are operator's justified costs. ${ }^{9}$

First it has to be noted that the terminology urgent supply (terminology nujna is used in the Slovenian language and in the original text) is not optimal. The term is used to differentiate it from the term emergency supply (terminology zasilna is used in the Slovenian language and in the original text), used in Article 44 of the EZ-1, which primarily regulates the situations of supplier insolvency and in cases where none of the suppliers want to conclude a contract with an individual consumer. Semantically it would be better if a different expression was used, since the term 'urgent' hints at a temporal scope, which is not the essence of the provision. We suggest that current urgent supply from Article 51 be renamed as emergency supply (zasilna oskrba in Slovenian language) and instead of emergency supply, the

\footnotetext{
${ }^{8}$ Directive 2009/72/EC of 13 July 2009 concerning common rules for the internal market in electricity and repealing Directive 2003/54/EC, paragraphs 7 and 8 of the Article 3, available at: https://eur-lex.europa.eu/legalcontent/EN/TXT/HTML/?uri=CELEX:32009L0072\&from=en (August 10, 2018).

${ }^{9}$ Energy Code (2014) with amendments, available at http://www.pisrs.si/Pis.web/pregledPredpisa?id=ZAKO6665 (March 12, 2018).
} 

and Urgent Supply of Electrical Energy in Slovenian Legal Framework

terminology replacement supply is more appropriate (nadomestna oskrba in Slovenian language).

Most importantly for an understanding of the regulatory framework and its consequences are paragraphs 1 and 2 of Article 51 of the EZ-1. Paragraph 3 in the same article is mainly an operative rule, ensuring that a potentially vulnerable consumer is informed of his/her rights, as well as giving the distribution operator a public authorization to regulate the matter further on the level of executive regulation, in accordance with Article 51 of the EZ-1. Paragraph 4 is mainly aimed at ensuring the adequate financing of the distribution operator, so that he/she may provide urgent supply to individuals in need.

According to paragraphs 1 and 2 of Article 51, it is thus forbidden to disconnect a household consumer, who, due to his/her financial situation, social circumstances and living conditions, is unable to ensure himself/herself another source of energy for household use, which would cause him/her the same or lower costs for the most urgent household supply from electricity network or lower his/her withdrawal of energy under the quantity or power. This is according to circumstances (season, temperature conditions, place of habitation, health condition and other similar circumstances) absolutely necessary, so that an endangerment of life and health of the consumer and persons living with him/her does not occur. There are thus two main elements comprising the norm; the personal element and a further factual element, which aims at the protection of a legal good quality of life and health.

The protected persons are the 'vulnerable consumers', a notion which includes all those individual human beings, which are household consumers (a household consumer is, according to point 13 of paragraph 1, Article 4 of the EZ-1, a consumer who buys electrical energy for his/her own use in a household, which excludes use for performing commercial or professional activities), ${ }^{10}$ whose specific social situation does not enable them to ensure another cost-accessible source of energy for household use. In legal practice, the aforementioned is mainly a factual question, and since the right of access to cost-accessible electricity is a basic human right as part of the right to an adequate standard of living, individual circumstances need to be taken into account when assessing whether someone is a potential beneficiary of the 'urgent supply' provision in the Slovenian EZ-1.

Regarding the further factual element, namely the protection of life and health, it has to be stated that it is, in essence, a factual question of medical science in each individual case. It thus raises the question, which quantity or power is absolutely necessary, that an endangerment of life and health of the consumer and persons living with him/her does not occur. Even though each individual case needs to be

${ }^{10}$ Energy Code (2014) with amendments, available at http://www.pisrs.si/Pis.web/pregledPredpisa?id=ZAKO6665 (March 12, 2018). 
assessed, some generalized comments may be made. If there is, for example, a temperature limit under which human life and health is intrinsically endangered, this would mean that at least in the coldest days of winter in Slovenia, most individuals who, due to their social circumstances, are unable to ensure an alternative source of heating, would be entitled to urgent supply under Slovenian energy law (Article 51 of the EZ-1).

The phrase 'endangerment of life and health' is thus the key terminology that needs to be interpreted. According to the grammatical interpretation it would seem at first sight that both life and health need to be endangered, that therefore a mere endangerment of health does not suffice for legal signs to be fulfilled in an individual case. However, such a viewpoint is mistaken and oversimplified, since this would mean that the use of the term 'health' would be redundant. Since we have to assume that the phrase was written by the legislator on purpose and not incidentally, the opposite conclusion has to be made, that namely both life and health are protected and that also the endangerment of health means the fulfilment of legal signs of the paragraph 2, article 51 of the EZ-1. This can be claimed $a$ fortiori, since the teleological interpretation shows that the intention of the legislator was to protect both health and life as legal goods. Even from a purely economic viewpoint, not only death, but also health issues in individuals can cause the costs of public healthcare to rise and is therefore undesirable from a policy standpoint. The correctness of such a claim is furthermore substantiated by the fact that the right to health in and of itself is a human right, which can be claimed to be a part of right to life, yet goes further in scope and depth. It is included in many international treaties, in which the Republic of Slovenia is party to, and which are, according to Article 8 of the Constitution of the Republic of Slovenia, in terms of hierarchy of legal acts, hierarchically higher than legislation. Examples of such treaties are the Universal Declaration of Human Rights (Article 25), International Covenant on Economic, Social and Cultural Rights (Article 12.1) and others. ${ }^{11}$ It is thus clear that paragraph 3, article 51 of the EZ-1 protects individuals not only when their life or lives of persons living with him/her are endangered, but also when 'merely' their health is at risk, due to their social situation.

\section{$4 \quad$ Health Concerns in Winter Months}

In connection with the endangerment of health of vulnerable consumers, winter months are usually the most problematic. However the question remains, what are the factual circumstances that enable the key legal terminology from Article 51 of the EZ-1, namely 'endangerment of life and health', to be fulfilled in individual cases. The relevant medical research evidences that low ambient temperatures are

11 UNHCR \& WHO Fact Sheet No. 31, The Right to Health (2008), available at: http://www.ohchr.org/Documents/Publications/Factsheet31.pdf (March 12, 2018); CESCR General Comment No. 14: The Right to the Highest Attainable Standard of Health (Art. 12) (2000), available at: http://www.refworld.org/pdfid/4538838d0.pdf (March 12, 2018). 
generally, by themselves, enough for the endangerment of life and health to be present.

Low ambient temperatures are namely a challenge for human health, as death rates are the highest during cold winter months due to exposure. In different countries this phenomenon has been described as excess winter mortality (Hassi et al., 2005). This is even more relevant in regards to current problems, namely ischemic heart disease, which is likely linked with mortality and low indoors temperature in contrast to low temperature outdoors (The Eurowinter Group, 1997). Nevertheless, different studies have shown that low outdoors temperature is a major factor concerning a higher chance for unfavourable cardiovascular reaction, for example for increased blood pressure; changed myocardial performance could namely lead to a stroke, arrhythmias and myocardial infarctions (Zhang et al., 2012).

Cold outdoor temperatures are a risk for health of human beings, and at different levels can cause an inability to work efficiently. Exposure to cold temperatures can influence the health and well-being, as well as lowering productivity and heightening health care costs in terms of health care planning. For preventive and protective measures to be assured, it is necessary to first identify cold related symptoms and diseases and to identify groups of people that are most prone to morbidity at low temperatures. Most of the adverse health effects due to low temperatures can be prevented by preventive and protective measures (Hassi et al., 2005). There does not seem to be a reason to treat the exposure to cold indoors differently in this regard.

Furthermore, when the temperature is low, the body tries to maintain normal temperature by a mechanism called sympathic activity, resulting in vasoconstriction. Loss of heat is lower, but blood pressure is higher (Modesti et al., 2006; Youn et al, 2007). Therefore low temperatures are a risk factor for different cardiovascular diseases, such as hemorrhagic stroke and myocardial infarction (Marchant et al., 1993; Morabito et al., 2011).

Woodhouse et al showed that in an elderly population a decrease of $1^{\circ} \mathrm{C}$ in ambient temperature was associated with the rise of systolic blood pressure by $1.3 \mathrm{mmHg}$ and a rise by $0.6 \mathrm{mmHg}$ in diastolic blood pressure (Woodhouse et al., 1993). Additionally, certain research has showcased the mechanism that raises blood pressure is linked with mortality and a low ambient temperature (Hong et al., 2013: 540).

Not only that, but a clear association between low ambient temperature and intracranial bleeding was reported by an international study, where in the case of elevated systolic blood pressure, exposure to low ambient temperature $\left(10^{\circ} \mathrm{C}\right)$ for several hours increases the risk of intracranial bleeding (Zheng et al., 2016). 
Another study has shown that cold related mortality was connected to high mean winter temperatures, low living-room temperatures and limited bedroom heating. Additionally, there was an increase in mortality observed in a case of cooler homes and when individuals are wearing fewer clothes. Low temperatures were found to have an effect on our body and are responsible for cold-related deaths. In the case of cold, the body responds with haemoconcentration, which leads to arterial thrombosis and a resistance to respiratory infections is lowered (The Eurowinter Group, 1997).

Based on the guidelines from the National Institute for Health and Care Excellence, more attention should be given to vulnerable people who live in cold homes and are sensitive to cold. According to the guidelines, this is because of the state of health (cardiovascular system disease) or any kind of disability. According to the guidelines, the word's vulnerable refers to people with cardiovascular conditions, people with respiratory conditions (in particular, chronic obstructive pulmonary disease and childhood asthma), people with mental health conditions, people with disabilities, older people (65 and older), households with young children (from newborns to school age), pregnant women and people with a low income. ${ }^{12}$

All of the above clearly shows that relevant medical research supports the claim that life and health are endangered per se when the ambient temperature falls beneath a certain threshold (around $10^{\circ} \mathrm{C}$ ), which is an occurrence in most buildings and apartments, at least during the coldest days of winter in Slovenia.

\section{De Iure et de Facto - Executive Regulation and Practice}

According to article 153 of the Constitution of the Republic of Slovenia, executive regulation has to be based on the legislation and be in congruence with it. ${ }^{13}$ Moreover, according to the legal principle of legality, only codes can determine rights and obligations. We have thus far devoted our attention, more or less, exclusively to the level of codes in terms of the hierarchy of legal acts. However, due to the public authorization given in paragraph 3 of Article 51 of EZ-1, the level of executive regulation is immensely important in practice in ensuring that vulnerable consumers actually get the required standard of protection. Regarding the level of executive regulation and its implementation in practice however, it has to be noted that it is not in accordance with the law, namely article 51 of the EZ-1.

\footnotetext{
${ }^{12}$ National Institute for Health and Care Excellence NICE guideline NG6: Excess winter deaths and morbidity and the health risks associated with cold homes (2015), available at: www. nice.org.uk/guidance/ng6 (March 12, 2018).

13 Constitution of the Republic of Slovenia (1991) with amendments, available at: http://www.pisrs.si/Pis.web/pregledPredpisa?id=USTA1 (March 12, 2018).
} 
First of all it has to be noted that the matter should be addressed on the operative level in System operating instructions from Article 144: however the current valid System operating instructions ${ }^{14}$ do not address the issue. Yet it is addressed in the executive regulation, named Common, conditions for supply and withdrawal of electrical energy from the distribution network of electrical energy (hereinafter Common conditions), and in a further regulation named Act regarding criteria and rules for ensuring urgent supply of electrical energy (hereinafter Act), which is simply unacceptable, especially taking into account Article 553 of the EZ-1. This means that a judge may not use such an executive regulation when deciding a case, since it is an exceptio illegalis, taking into account article 125 of the Constitution of the Republic of Slovenia ${ }^{15}$ and the first paragraph of article 3 of the Act of Courts (hereinafter ZS). ${ }^{16}$ In practice however, the above executive regulations are routinely applied to the questions of urgent supply, so we will have to see if, even when the fact that it is regulated within the wrong executive regulations is neglected, the current solution is in accordance with the law.

Again the answer seems to be no, especially when taking into account the practical application of the norms, since the above-mentioned executive regulation is far more restrictive than Article 51 of the EZ-1, and thus entails a breach of the legal rights of potential vulnerable consumers concerned. Article 53 of the Common conditions is reasonable enough, stating that a consumer has the right to urgent supply if he/she submits sufficient evidence that disconnection would cause an endangerment of life and health of the individual and persons living with him/her. ${ }^{17}$ According to Article 51 of the EZ-1, it should state 'of the individual or persons living with him', the provision itself (aside from the already mentioned technical error) is adequate. Article 54 of the Common conditions, the Act and especially how it is interpreted in practice by the system operator, further limits the scope of the rule by stating that two things are to be taken into account in deciding the heating season or the opinion of a medical professional (doctor of medicine) that a person requires the use medical devices, which necessarily require electrical energy to function. ${ }^{18}$ This is defined too narrowly, since Article 51 of the EZ-1 explicitly states that such factors to be taken into account are not numerus clausus, using the terminology: '...season, temperature conditions, place of habitation, health

${ }^{14}$ System operating instructions for the distribution network of electrical energy (2011), available at: http://www.pisrs.si/Pis.web/pregledPredpisa?id=NAVO1023 (March 12, 2018). 15 Constitution of the Republic of Slovenia (1991) with amendments, available at: http://www.pisrs.si/Pis.web/pregledPredpisa?id=USTA1 (March 12, 2018).

16 Act of Courts (2007) with amendments, available at: http://www.pisrs.si/Pis.web/pregledPredpisa?id=ZAKO332 (March 12, 2018).

${ }^{17}$ Common conditions for supply of electrical energy from the distribution network (2007), available at: http://www.pisrs.si/Pis.web/pregledPredpisa?id=DRUG2905 (March 12, 2018).

${ }^{18}$ Common conditions for supply of electrical energy from the distribution network (2007), available at: http://www.pisrs.si/Pis.web/pregledPredpisa?id=DRUG2905 (March 12, 2018). 
condition and other similar circumstances... ${ }^{19}$ Similar can be claimed of the Act, which in general is seemingly reasonable, Article 3 of the Act explicitly states that the only two reasons for granting protection are season and temperature conditions and the medical condition of the individual consumer. Since Article 51 of the EZ1 , as explained above, only exemplifies the personal circumstances, which are the condition for granting protection to an individual consumer, meaning that it is not a numerus clausus, this again is too narrow, restricting the scope of rights of individuals in an unacceptable fashion.

The practical interpretation, however, is even more problematic. In practice urgent supply is usually not granted unless a statement by a medical professional is given, in which he/she states that the individual person would die, unless he/she would have access to electricity. Other claims, especially those related to season and its health consequences, as presented in the previous chapter, are often routinely denied. Out of publicly available data, we can discern that in the year 2015 (no data is available for 2016), not even one individual was granted the status of a vulnerable consumer and received urgent supply. ${ }^{20}$ The same was true for years $2014^{21}$ and $2013 .{ }^{22}$ Since the benchmark Energy Outlook 2017, prepared by the International Energy Agency, estimates energy poverty rates in Slovenia between 5 and 27 percent, ${ }^{23}$ something is clearly wrong with the interpretation of the laws and executive regulations in legal practice. The fact that these cases are not tried in court where the inadequacy of executive regulation and its incongruence with legislation as well as sloppy application would be exposed, it is in our opinion largely connected with the fact that vulnerable consumers (generally speaking) do not have the means or sufficient knowledge to seek legal counsel in order to address the potential breach of their rights by the competent authorities. This is even more troublesome, since 'expenses of urgent supply of vulnerable consumers are operator's justified costs,' according to paragraph 4 of Article 51 of the EZ-1, meaning that there is no clear economic reason for the provider of the economic public service to act this way, except that the manager must argue in front of the representatives of the owner (Republic of Slovenia) as to why the justified costs have suddenly risen to unprecedented heights. Perhaps there are simply some problems with the model in which a public authorization is given to an economic

\footnotetext{
19 Energy Code (2014) with amendments, available at http://www.pisrs.si/Pis.web/pregledPredpisa?id=ZAKO6665 (March 12, 2018)

20 Audited Yearly Report SODO (2015), available at https://www.sodo.si/kdo-smo/letnaporocila (March 12, 2018).

${ }^{21}$ Audited Yearly Report SODO (2016), available at https://www.sodo.si/kdo-smo/letnaporocila (March 12, 2018).

${ }^{22}$ Audited Yearly Report SODO (2017), available at https://www.sodo.si/kdo-smo/letnaporocila (March 12, 2018).

23 Energy Access Outlook 2018: From Poverty to Prosperity (2018), available at: http://www.iea.org/publications/freepublications/publication/WEO2017SpecialReport_Ener gyAccessOutlook.pdf (March 12, 2018).
} 
public service, which is essentially a state-owned company, to carry out tasks that have the nature of a social corrective.

Due to all of the above, it is clear that executive regulation and its practical implementation do not offer the vulnerable consumers, as defined by Article 51 of the EZ-1, the protection afforded to them by the letter of the law. We can speculate that this is due to potential financial consequences of a correct application of the relevant legislation and we will seek to analyse how other states are dealing with the issue.

\section{Protection of Vulnerable consumers in a Comparative Overview}

There are two main elements of the protection of vulnerable consumers that have to be taken into account in order to understand different legislative solutions enacted by different states and how they compare to each other. The first element is the actual scope of the notion 'vulnerable consumer' and the second element is the protective measures taken by the states. We will focus primarily on the first one in our analysis, since it is the one determining the scope of the legislation, namely how broad the group of legally protected consumers is or should be. The measures taken, whether in the context of free access to electricity model, or the payment of support model, are less disputed and less problematic, as long as the chosen model actually ensures that entitled individuals are granted adequate and effective access to electricity, even when they are lacking funds to buy electricity on the liberalized part of the market.

Analysis shows that there are three main models used for defining the subjects, who qualify as vulnerable consumers and who are thus the beneficiaries of the protective legislation. These three are the income threshold model, the share of income required to meet adequate energy requirements and the consumer characteristics model (Pye et al., 2015: 28).

The Slovenian model is by its nature a consumer characteristics model, because the law defines the characteristics that an individual consumer needs to meet in order to be recognized as a vulnerable consumer and in order to be granted protective measures. Such characteristics are not based simply on income, but also take into account a complex array of factors, such as health condition, living conditions, etc. Such a model should, in theory, provided that the relevant characteristics are indeed relevant and carefully selected, grant the highest degree of protection, since it is focused on the individual and his/her specific circumstances. In practice however, such a model can, in many cases, offer a lower degree of protection for individuals, due to the fact that it is less cost-effective, since each case has to be carefully weighed. This can lead to arbitrary refusal of claims for protection, since such individuals often do not have the means or legal knowledge to protect their right, as is indeed occurring in the Slovenian system. Similar models, with different degrees 
of successful practical implementation can be found in other states, for example in Belgium and in Spain.

An example of an income threshold model is the Romanian model. In Romania, a vulnerable consumer is defined in the Law 123/2012 as a 'final client belonging to a category of residential clients who, because of their age, health status or low income, is at risk of social marginalization and to prevent such risk is a beneficiary of social protection, including financial protection. ${ }^{24}$ Even though the first part of the definition hints that individual characteristics could be taken into account, the second part, where the scope of the notion 'vulnerable consumer' is limited to a beneficiary of social protection, clearly makes it a simple and straightforward income threshold model. The limit of income, under which an individual is deemed to be a beneficiary of social protection, is namely defined in the Law 196/2016 according to an income based threshold. ${ }^{25}$ Such a model is, in our opinion, too superficial and generalized as it might on one hand grant the status of vulnerable consumers to individuals who in fact do not need as much electrical energy as others (individuals residing in warm parts of the country) and on the other hand it might prevent some people who undoubtedly should be beneficiaries from being granted the status of a vulnerable consumer (for example an individual who needs specific medical equipment in his/her house in order to survive, which uses a large amount of electricity).

The last model, the share of income model, is implemented for example in the United Kingdom. Taking into account the definition by the Department of Energy and Climate change, based on Hills, vulnerable consumers (fuel poor consumers, a somewhat broader notion is used by the above-mentioned body) are those whose income is below the poverty line, and their energy costs are higher than what is typical for their household type. ${ }^{26}$ This model represents the middle ground between the two above models, taking into account individual characteristic, but still being quite general and broad in its approach.

From the standpoint of the protection of consumer we can conclude that the consumer characteristics model is the optimal one in defining the scope of the protective provision, provided that the individual state can and is willing to allocate sufficient funds in the public budget in order to ensure its actual implementation in

24 Law 123/2012 on Electrical Energy and Natural Gases (2012), available at www.electrificarecfr.ro/elegi/legi/L123.pdf (March 12, 2018), see Mutatescu, V. [et al] On the residential energy consumers' vulnerability in Romania, Foren 2016 (Costinesti).

25 Law $123 / 2012$ on Electrical Energy and Natural Gases (2012), available at www.electrificarecfr.ro/elegi/legi/L123.pdf (March 12, 2018), see Mutatescu, V. [et al] On the residential energy consumers' vulnerability in Romania, Foren 2016 (Costinesti).

${ }^{26}$ Hills, J., Final Report of the Fuel Poverty Review, Case Report 72 (2012), available at: sticerd.lse.ac.uk/dps/case/cr/CASEreport72.pdf (March 12, 2018). 
practice, not only 'on paper'. In political terms, if the right public policy is actually implemented.

\section{$7 \quad$ Conclusions}

While it is entirely possible that the solution in Article 51 of the EZ-1 is economically untenable (a more detailed economic analysis is needed, which to our knowledge has not been performed), laws should be upheld as they are written. Since in practice the access to protection granted under article 51 of the EZ-1 is severely limited due to a highly conservative (as shown above, too restrictive) interpretation of the term 'endangerment of life and health', we have to conclude that many individuals who are entitled to protection as vulnerable consumers are simply not getting that protection, even more so because the executive regulation is unacceptably limiting the rights of individuals. We have clearly shown that at least during the winter months, if we apply the existing laws correctly, taking into account medical science, practically all consumers with insufficient funds to finance their heating are potential beneficiaries of the vulnerable consumer provision from Article 51 of the EZ-1.

Since the consumer characteristic model is the one granting the most rights to individuals, it is indeed the appropriate model. However the Energy Agency of the Republic of Slovenia is the supervisory organ, which should ensure that the laws are being applied and that executive regulation is in accordance with the EZ-1. If such a system simply does not function in practice, perhaps the legislator should look for an alternative 'best practice' solution, such as in the Nordic states, which have the lowest levels of energy poverty in Europe, and ascertain if any of their models are economically viable for the Slovenian public budget. To summarize, Article 51 should either be applied in practice, not only in theory, or the legislator should perform a well-thought out revision. The current situation, where during the winter months, anywhere between 41.925 and $226.396^{27}$ are not receiving the urgent supply that they are entitled to by law, is simply unacceptable.

\section{References}

Bates, B. (1990) Information as an economic good: A reevaluation of theoretical approaches, In: Mediation, information and communication - Information and behaviour, Volume 3, (New Brunswick: Transaction), pp. 379-394.

Bradbrook, A. J. [et al] (2006) Placing access to energy services within a human rights framework, Human Rights Quarterly, 28(2), pp. 389-415, doi: 10.1353/hrq.2006.0015.

27 According to World Energy Outlook 2017 estimates, applied to the total number of household consumers according to last available data - 838.505. World Energy Outlook 2017 (2017), available at: https://www.iea.org/weo2017/ (March 12, 2018). 
Hassi, J. [et al] (2005) Impacts of cold climate on human heat balance, performance and health in circumpolar areas, International Journal of Circumpolar Health, 64(5), pp. 459-467, doi: 10.3402/ijch.v64i5.18027.

Hong, Y. C. [et al] (2013) Identification of RAS genotypes that modulate blood pressure change by outdoor temperature, Hypertension Research, 36(6), pp. 540-545, doi: 10.1038/hr.2012.218.

Kalihoff, A. (2011) Why democracy needs public goods (Plymouth: Lexington Books).

Kotchen, M. (2014) Public goods, In: Whitehead, J. \& Haab, T. (eds.) Environmental and Natural Resource Economics: An Encyclopedia (Greenwood: ABC-CLIO).

Marchant, B. [et al] (1993) Circadian and seasonal factors in the pathogenesis of acute myocardial infarction: the influence of environmental temperature, British Heart Journal, 69(5), pp. 385-387.

Modesti, P. A. [et al] (2006) Weather-Related Changes in 24-Hour Blood Pressure Profile Effects of Age and Implications for Hypertension Management, Hypertension, 47(2), pp.155-161.

Morabito, M. [et al] (2011) Innovative Approaches Helpful to Enhance Knowledge on Weather-Related Stroke Events Over a Wide Geographical Area and a Large Population, Stroke, 42(3), pp. 593-600, doi: 10.1161/STROKEAHA.110.602037.

Pye S. [et al] (2015) Energy poverty and vulnerable consumers in the energy sector across the EU: analysis of policies and measures (Stockholm: Insight_E).

Rademaekers, K. [et al] (2016) Selecting Indicators to Measure Energy Poverty (Rotterdam: Trinomics).

The Eurowinter Group (1997) Cold exposure and winter mortality from ischaemic heart disease, cerebrovascular disease, respiratory disease, and all causes in warm and cold regions of Europe, Lancet, 349(9062), pp.1341-1346.

Tomažič, L. M. \& Bratina, B. (2015) Corporate governance and management in the electricity market between economic public service and free market, with emphasis on energy contracting, Masters thesis (Maribor: Ekonomsko-poslovna fakulteta).

Youn, J. [et al] (2007) Arterial stiffness is related to augmented seasonal variation of blood pressure in hypertensive patients, Blood Press,16(6), pp. 375-380.

Woodhouse, P. R. [et al] (1993) Seasonal variation of blood pressure and its relationship to ambient temperature in an elderly population, Journal of Hypertension, 11(11), pp. 1267-1274.

Zhang, Y. [et al] (2012) Cardiac-specific knockout of ET A receptor mitigates low ambient temperature-induced cardiac hypertrophy and contractile dysfunction, Journal of Molecular and Cellular Biology, 4(2), pp. 97-107, doi: 10.1093/jmcb/mjs002.

Zheng, D. [et al] (2016) Low Ambient Temperature and Intracerebral Hemorrhage: The INTERACT2 Study, PLoS One, 11(2):e0149040, pp. 1-14, doi: 10.1371/journal.pone.0149040. 

